\title{
The Multilingualism of Dutch Rhetoricians: Jan van den Dale's Uure van den doot (Brussels, c. 1516) and the Use of Language
}

\author{
Arjan van Dixhoorn
}

\section{Introduction}

One of the most important trends in the communication history of Western Europe is the often neglected rise of communal theatrical cultures after $145^{\circ}$. That is to say, the advent of the printing press, the surge in manuscript production, and the technological innovations of visual culture were chronologically tied to the flourishing of theatrical cultures. In fact, evidence from all over urban Europe indicates that print and manuscript culture as well as visual and theatrical culture became increasingly interdependent and integrated on the level of content and form, skills and techniques, and the creative communities that patronized, sustained, developed, appropriated and used them. At the intersection of these modes and communities were regional cultures of performative literature (dramatized and poetical eloquence typical of early modern urban life). ${ }^{1}$ The growth of theatrical culture at the intersection of other innovative media cultures suggests that even the combination of the printing press and manuscript culture could not meet the thirst for the kind of learning derived from texts.

This theatrical world is the context which any study of the spoken and written word, of language strictly speaking, must take into consideration. The early modern world of Christian Europe was a world in which the spoken word (and its arts, which are rhetoric and music) functioned as the model for communication in general. This essay will explore the role of language in one of the regions

1 Works that trace the development of a new theatrical culture include: Arnade, Realms of Ritual; Ashley and Hüsken, Moving Subjects; Hanawalt and Reyerson, City and Spectacle; Cauchies, Fêtes et ceremonies; Fischer-Lichte, Horn and Umathum, Wahrnehmung und Medialität; Kipling, Enter the King; Lavéant, Théâtre et culture dramatique d'expression française; Lecuppre-Desjardin, La ville des ceremonies; Van Bruaene, Om beters wille; Van Dixhoorn, Lustige geesten. For the development of print culture and the flourishing of manuscript culture in the fifteenth century, Würgler, Medien in der frühen Neuzeit, particularly 69. 
of urbanized Europe, the Low Countries, where Dutch-speaking communities developed a theatrical culture based on the liberal arts that chose the art of rhetoric as its paradigm. The focus will be on the sociolinguistic communities of rhetoricians that gathered in the so-called chambers of rhetoric from the early decades of the fifteenth century onwards, starting in the cosmopolitan creative cultures of the urban networks of Brabant and Flanders. The prototype of the chamber of rhetoric was consolidated around 1450 and the rhetorical knowledge, practices, and techniques that the early chambers developed became paradigmatic for vernacular literary culture in Dutch after the $1480{ }^{2}{ }^{2}$

The paradox of rhetorician life is however that it is the institutionalization of the increasingly important role of the written or even printed text as the basis for a reading, reciting, or performance among live audiences. A written text in early modern culture was completed orally: the performance of a memorized written text or its reading aloud gave it its finishing touch. While Pleij has stressed the aurality of the production, completion, and reproduction of written texts, Kramer has argued how in rhetorician farcical culture most theatrical action was typically verbalized simultaneously by the actors while performing the acts. Such a verbalized Rabelaisian world required the creation of a literary language for the material, organic, dirty, common, low, deformed, decaying, inverted, bizarre, and confusing features of life. At the same time, the farcical was characterized by a special fascination for the anatomy of language, and its ambivalent potential for miscommunication. ${ }^{3}$

Although Kramer focused on the farcical language of the rhetoricians, these features, such as the fascination for the material and organic world of the senses or the anatomy and communicative quality of language, were also typical of rhetorician language in general. This is evident in the common use of word stacks, neologisms, meaningless or ambivalent words, word extensions, synonym stacks, and homonyms. The sensuous language of the rhetoricians used expletives, swearing, oath-taking, incantations, colloquial vocabulary, nonsense and street terms; it transgressed and merged jargons, inversed linguistic snobbery, and abundantly used praise-abuse-forms. If the context of conversation, literary ceremony and ritual, performances, and competition of the chambers of rhetoric is taken into account as well, the world of the rhetoricians meets many of qualities of oral cultures identified by Walter Ong. ${ }^{4}$

2 For introductions to the culture of the chambers of rhetoric in English see Van Dixhoorn, 'Chambers of Rhetoric'; and Van Bruaene, ' "A wonderful triumfe".

3 Pleij, Het gevleugelde woord, pp. 253-62; Kramer, Mooi, vies, knap, lelijk, passim.

4 Ong, Orality and Literacy, pp. 36-70. 
The features of orality that were most evident in rhetorician culture are the use of an additive, enumerative, aggregative rather than an analytic style. Rhetorician language, meant for oral and performative transmission and memorization in absence of manuscripts or printed texts and images to fall back upon instantly, had a strong preference for epithets and other formulaic forms, for a redundant and copious style. Since the oral utterance and the performance are ephemeral, Ong argues, the mind must be supported to focus attention during the performance. Redundancy, repetition, and volubility keep speaker and hearer on track, which explains the method of the ancient rhetoricians called copia or amplification. ${ }^{5}$

Ong argues that the conceptualization and verbalization of knowledge in an oral and performative context, that is, in the absence of recording media such as parchment or paper, will use close references to the human life world, particularly the interaction of human beings, a technique which is evident in the use of allegory and personification in rhetorician culture. Other techniques that oral and performative cultures use to stimulate memorization (that is to make the argument or narrative stick in memory) are the use of an agonistic style; of verbal and intellectual combat and games (such as riddles), bragging, of tongue-lashing the opponent, of name-calling, as well as descriptions of physical violence. Apart from the use of 'heavy' language, oral memory also works with 'heavy' characters, heroic and bizarre figures that organize 'experience' in memorable form since, according to Ong, the colorless cannot survive in oral mnemonics. Paradoxically, such oral devices were used to the full not in the medieval literature of, or so it seems, less literate times, but instead in a rhetorical culture that heavily depended on manuscript and printed texts and images. ${ }^{6}$

This essay thus focuses on a culture which was characterized by the interdependency of oral, visual, performative, and written means of storage and communication of experiences and ideas. One of its features was a chronic lack of easily accessible knowledge. This essay argues that the language of rhetoricians that had to deal with these characteristics was a hybrid that included the visual and performative through ecphrasis (the lively description of people, places, works of art, events, acts) and theatricality (that is by performing in front of a live audience), and the combination of these, by mimicking or simulating such a performance. ${ }^{7}$

5 Ibidem.

6 Ibidem.

7 Geertz, Negara; Greenblatt, Renaissance Self-fashioning; Fischer-Lichte, 'Wahrnehmung und Medialität'; Kotte, 'The transformation of a ceremony'; Eversmann, 'Introduction'; McGavin, 
The aim is to study how such multilingualism, taken to be the use of multiple languages and jargons, defined Dutch-speaking culture. The rhetoricaltheatrical paradigm was produced and reproduced in the textual and performative traditions of the communities that created and developed its matrix of rules and practices. The knowledge and language of the rhetoricians provided the raw material to be mastered in order to be able to learn and to teach. Their main method was the 'extraction' of meaning by translating and adapting narratives or arguments from one mode, language, jargon, or form into another in the hope of bringing the original meaning at play in a different cultural context. ${ }^{8}$ In order to succeed, the rhetoricians created a new literary language that survived well into the seventeenth century. The work of Jan van den Dale, a late fifteenth- and early sixteenth-century rhetorician of Brussels, will be used to show how the early modern Dutch rhetorician language absorbed the vocabulary of the hybrid and eclectic sources of knowledge used and adapted by its makers.

\section{The Multilingualism of the Rhetoricians}

Nineteenth-century literary historians often deplored the transition of the seemingly natural and pure Dutch of earlier generations that can be termed the clergie-tradition and of the lyrical Dutch of medieval literature into a hybrid, didactic, artificial, 'vulgar' language of the literary burgher-amateurs that the rhetoricians were supposed to have been. ${ }^{9}$ The rhetorical turn was indeed highly visible in the language deployed by rhetoricians and associated with

Theatricality and Narrative. And for the rhetorical method of ecphrasis see, Curtius, European literature and the Latin Middle Ages, pp. 69, 194.

8 For the sixteenth-century debate on translation see among others contempory texts edited in Hermans, Door eenen engen hals; Hermans, "Translating "Rhetorijckelijck" or "Ghetrouwelijck"'; Hemelaar, 'Translating the Art of Terence'. The role of translation in the art of rhetoric is also exemplified in the prologue to Jan Pertcheval's Camp van der doot where he claimed that the work 'vol is van geestelijke verstandenisse, vol van scriftueren ende figuren, vol van exempelen der poeten, ende nae de conste van de rethorijc zeer constelijc geset' (rich in understanding, rich in scriptures and figures, rich in exempla of the poets, and artfully composed according to the art of rhetoric'. Quoted in Pleij, Het gevleugelde woord, p. 322 .

9 Pleij, 'Is de laat-middeleeuwse literatuur in de volkstaal vulgair?', and idem, Het gevleugelde woord which traces the language and literature of the rhetorician to an oral world. For a traditional view of the rhetoricians and their language, see Porteman and Smits-Veldt, Een nieuw vaderland voor de muzen, pp. 24-167. 
their chambers of rhetoric ever since. Although the pioneers of a more serious study of rhetorician literature were also interested in their vocabulary, their use of language has been largely ignored and the transformation from clergie to rhetorike has never been seriously studied, mainly because the literary qualities of rhetorician texts were not appreciated for centuries, and still are rather controversial to say the least. ${ }^{10}$ Before turning to Van den Dale's work and use of language, the impact of the rhetorical turn on the Dutch language of performative literary culture as it came into existence, must be briefly explored.

Why exactly the Dutch rhetorical language became such a hybrid is not clear. It is evident however that the transformation, if not initiated, at least was furthered by the establishment of the chambers of rhetoric and their adaptation of the rhetorical knowledge and practices of the seconde rhétorique. The communities of rhetoricians of the Dutch-speaking areas borrowed the core of their technical terms from the world of the seconderhétorique of France and the French-speaking Low Countries. The rhetoricians borrowed key terms such as rhetorique/retorike, retorisien (from rhétorisien), and retoriker (from rhétoriqueur); generic terms such as esbattement, refrein, rondeel, ballade; the names of key institutional figures, such as the prince (the ceremonial leader) and the facteur (the composer of texts meant for publication); as well as key notions such as scientie, and sin.11

The notion of $\sin$ (meaning) was crucial to the translatio-culture of the rhetoricians since it referred to their main method: the extraction and transmission of meaning from one medium into another. The rhétoriqueurs apparently also highly valued the concept of 'scens' from which $\sin$ must have been derived. A prize-winning song by Jean Froissart, most likely submitted to a Puy-contest, praised love as the influence leading to 'sens, force, savoir'. The composer Guillaume de Machaut argued that 'scens est qui tout gouverne'. The notions of 'sin', 'sinne', 'sinnen', were so essential to Dutch rhetorician culture that its

10 My view on the development of the language of rhetoricians as an artificial and national language has been influenced by Burke, Languages and Communities; Peter Burke, 'The jargon of schools'. See for older literature on the language of the rhetoricians: Génard, De zinnebeeldige taal der oude rederijkers; Drewes, 'Bijdrage tot een woordenboek van de rederijkerstaal'; and 'Enige bijzonderheden in het woordgebruik van de rederijkers; Mak, Rhetoricaal glossarium; Willemyns, 'Iets over de taal'; De Lange, 'Lessen: Historische gegevens met betrekking tot het taalgebruik'; Vuijk, and Eggermont, "Van hoe er zich twee vergaren tot elcker uren soet.

11 James-Raoul, 'Les arts poétiques des $\mathrm{XII}^{\mathrm{e}}$ et XIII ${ }^{\mathrm{e}}$ siècles; Lusignan, Parler Vulgairement. I owe the last reference to Prof. Laura Kendrick (Université de Versailles-St-Quentin-enYvelines). For the seconde rhétorique and the early modern practice of performative literature see, Arjan van Dixhoorn, 'Epilogue', pp. 423-62. 
prestigious allegorical plays were called 'spelen van sinne'. The neologism was once translated in the sixteenth century accounts of the city of Bruges as 'ung jeu moral, un jeu de sens'. ${ }^{12}$

The technical terms of the seconde rhétorique were introduced into Dutch in the 1440 s and had become widespread by the 1480 s when the paradigm of Dutch rhetoric became institutionally consolidated in Brabant and Flanders, but also in Holland and Zealand. Between the 1480 s and 1520 s regional networks of chambers of rhetoric built on regionally centered communities of rhetoricians and regional festivals were firmly established in these four Burgundian Dutch-speaking principalities. The different regional and local rhetorical cultures that they created were modeled after the successful proto-types developed in Flanders and southern Brabant. Despite regional and local variations, the rhetorician movement was able to develop a 'universal' discourse and use a 'universal' language with 'universal' forms of regulated speech. These were continuously adapted to new interpretations of the role of rhetoric in the field of knowledge, the position of the vernacular, and the authority of vernacular rhetoricians as compared to the 'citizens' of the other institutions of knowledge, particularly the Church, the State, and the universities: the clergy, the lawyers and councilors, the scholars, and the aristocracy. The unity in diversity mainly resulted from interurban networking among individual rhetoricians at festivals and other meetings, the homogenizing effects of successful chambers in their hinterlands, the fame of leading rhetoricians and the circulation of their texts in print, manuscript, and memory. ${ }^{13}$

The translation from French rhetorical knowledge, expertise, and technical terms into Dutch created a new culture, instead of a Dutch-language equivalent of the French Puys- and compagnies joyeuses. ${ }^{14}$ The novelty showed in the fact that the chambers of rhetoric were assembled from elements of the two older models. The Dutch refrein differed from the French ballade or the chant royal and the spel van sinne was different from the French morality plays and farces although the rhetoricians might have appropriated allegorical techniques from French examples. It has been argued that the spel van sinne was more deliberative than the French moralités that have survived. The basic structure of the Dutch allegorical play was derived from older traditions of morality plays and poetical debates, but also rather directly or so it seems, from the Latin,

\footnotetext{
12 De Bock, Opstellen over Colijn van Rijssele, pp. 117, 133.

13 See for the development of the chambers of rhetoric in particular, Van Bruaene, Om beters wille, and Van Dixhoorn, Lustige geesten.

14 Lavéant, 'The Joyful Companies'; Lavéant, 'Théâtre et culture dramatique d'expression française'; Reid, 'Patrons of Poetry'.
} 
scholastic tradition of the disputatio, quaestio, and quaestio de quodlibet of the universities. The argumentative techniques were enriched by the argumentative structures of theology and homology (ars praedicandi). ${ }^{15}$

Thus, sometimes technical terms were adopted and used to enrich Dutch rhetorical language, others were translated into an originally Dutch equivalent or a neologism, or were combined with Dutch terms (as probably happened in the spel van sinne). The refrein shows yet another shift from French into Dutch. The French refrain was the recurring line closing each stanza of the ballad and containing a sententio or judgment; which in the Dutch refrein, the main poetical form of the rhetoricians, was called stokregel: the French term in Dutch referred to the whole generic form, the term for the sententio was a unique Dutch neologism. Finally, with the model of the generic forms influencing their creation of new Dutch forms, the rhetoricians also adapted the intricate French rhyme schemes, and a love for and use of a rich, abundant, theatrical, and mimetic language full of neologisms and barbarisms. In so doing, the rhetoricians, in transforming the practices of vernacular learning and performative literary culture in Dutch, also altered its heart: they created an entirely new language that not only consisted of the older lyrical and 'clerical' Dutch, but also enthusiastically embraced barbarisms from Latin and French, and the various jargons of the region, some of which also used many Latin and French barbarisms (such as the language of the law, of bureaucracy, of medicine, and theology, and the jargon of the scholar in general).

The language of the rhetoricians can also be traced in all sorts of vernacular texts that show no immediate connection to the chambers of rhetoric (as the refrein and spelen van sinne do). Although it is highly likely that the rhetoricians played a crucial role in creating an artificial Dutch language, this cannot be proven at this point, simply because we would need to analyze a large sample of texts that are clearly rhetorician and others that lack the institutional mark. In any case, the textual tradition that uses rhetorician language extends widely beyond texts made for the institutional practices of the chambers of rhetoric. It is perfectly possible that most of these texts, from chronicles to anti-protestant polemics, and from natural histories to devotional books, were also created by members or alumni of chambers of rhetoric; there is no way of knowing this. It is just as possible that a larger community of vernacular men and women of letters used a certain language that had its source in the smaller community of incorporated rhetoricians. The hybrid difference of

15 Moser, De strijd voor rhetorica; Spies, '“Op de questye”'; Ramakers, 'Tonen en betogen'; Spies, 'Developments in sixteenth-century Dutch poetics'. 
this language, as compared to the older Dutch literary languages, or to French, Lower-German, and Latin, is consciously maintained. ${ }^{16}$

It should be stressed that the hybrid nature of the language of the rhetoricians far extended the use of various registers of the verbal languages that it absorbed. Even though spoken language was the standard, it intersected in various ways with visual means of communication: theatrical action, architectural structures, and images. These visual, theatrical forms mainly entered the lexicon of the rhetoricians through the rhetorical techniques of ecphrasis such as in vivid descriptions of forms, shapes, colors, and actions. Yet, action and visual culture were also used as distinct discursive elements in the building of an argument or a narrative. In line with a rhetorical tradition that viewed actio, or the visual, as part of pronunciation (the final stage of ancient rhetorical method), rhetoricians were famous for their use of tableaux vivants and pageants, and of course used action in their allegorical plays and farces by way of pronunciation (the art of clearly, vividly expressing a thought or argument). Rhetoricians were also fond of rebuses that alternated image and word in the construction of a sentence, but also show how the visual depended on the word, since the fun of the rebus is to translate the image into a word that 'solves' the sentence. ${ }^{17}$

A similar use of word and image can be seen in the rhetorical blazons: the emblems of the chambers of rhetoric whose combination of a motto, a name, and images were also used as a rhetorical genre. Somewhere in the early

16 See for example from the related French rhetorical tradition, Fabri, Cy ensuit le Grant et Vray Art de Pleine Rhétorique (1522) who writes in his prologue of the need of an ordered, that is an artificial, knowledgeable language versus a natural one. He adds that the three languages of learning, Hebrew, Greek, and Latin nourish the vernacular languages with their learned language. Learning had finally been translated into Latin, and was now being translated into French, which is why it is important to submit the French language to the rules of rhetoric. Later Fabri underlines the difference in meaning of words taken from Latin or Flemish (sic!), and continues to stress the importance of taking into consideration circumstances, audience, and topic.

17 See the argument in the 1555 French art of rhetoric by Antoine Fouquelin, La Rhétorique Française, dedicated to Mary, Queen of Scots, who argues that unlike words, actio and geste, are a visual language that can be understood by everyone: 'l'action et geste du corps, lequel donne quelque indice et signification du movement de l'esprit, émeut un chacun, memes les idiots et barbares', which is, according to him, why Cicero referred to actio et geste as 'quasi parole et eloquence: comme si le corps muet parlait par son geste et movement'. This was evidently the idea in rhetorician culture and the culture of eloquence at large. See in particular, Ramakers, 'Horen en zien, lezen en beleven'; Ramakers, 'Die Welt und die drei Begierden im Rederijkersdrama'. 
sixteenth century, or earlier, the creation of a new blazon to answer a prize question, in way similar to the refrein and spel van sinne, became part of the festival culture of the rhetoricians. The blazon was offered to the organizing chamber with a poem translating its meaning into spoken language. A similar view of the visual and performative as structuring elements of a rhetorical discourse is evident in the prizes awarded for welcoming ceremonies; or, often, the best celebrations (often including fireworks) during rhetorician festivals. Such a view of actio as part of the art of rhetoric was confirmed by the authorities whenever they used the expertise of rhetoricians (or humanists, for that matter) for the creation of the 'argument' of joyous entries, processions, and other ceremonial productions. ${ }^{18}$ The intimate link between the rhetorical arts and pictorial culture in the Dutch-speaking Low Countries was also evident from the fact that many rhetoricians were painters, and vice versa. The Antwerp guild of St Luke even famously came to embody this relationship when it incorporated the chamber of rhetoric of the Gillyflowers in 1480.

\section{The Language of Jan van den Dale}

The creation of rhetorician communities that were dedicated to sharing knowledge among themselves and with larger audiences must be understood as a response to the chronic lack of easily available knowledge that characterized early modern culture. Around 1500, the city of Brussels, the Brabantine centre of courtly culture, had become a stronghold of rhetorician culture, with Jan Smeken, Jan Pertcheval, and the painter Jan van den Dale (ca. 1460-ca. 1522) as the three leading rhetoricians of the Dutch-language knowledge community. Their work was highly influential in rhetorician culture at large.

This essay will only focus on one of Van den Dale's poems, printed by the Brussels printer Thomas van der Noot. It seems that Van den Dale acquired more fame than his fellow rhetoricians. When the rhetorician movement began to commemorate its founding fathers more systematically in the 1560 , Van den Dale was among them. The 1562 festival book of the famous Antwerp Landjuweel of 1561 claimed that Duke Philip the Fair had been such a great lover of the art of rhetoric that he had set several questions for the winning of a golden ring richly set with diamonds for the participant that would best solve them. The festival was attended by many excellent minds and great poets and

18 Bleyerveld, 'De negen geschilderde blazoenen'; Keersmaekers, 'Rederijkers-Rebusblazoenen'. For the use of rhetoricians as experts in public events see, Mareel, Voor vorst en stad, passim. 
was won by Van den Dale 'eenen vermaerden Retoricien', 'whose composition is still highly valued today'. ${ }^{19}$

Jan van den Dale acquired lasting fame through his allegorical poem Uure van den doot ('Hour of Death'). ${ }^{20}$ The poem, an ars moriendi of sorts, will be studied here as an example of the rhetorician's use of language. The popular booklet was reprinted well into the eighteenth century. ${ }^{21}$ Further proof of its popularity is provided by a Latin and a French translation. In 1561, the WestFlemish priest Jacobus Sluperius sent the rhetorician Marius Laurier a copy of De Spectro Bosingensi sive de Hora Fatali. The poem was published in his Poemata of 1563. A liminary letter by Hadrianus Hogius referred to the fact that the poem was an imitation of Van den Dale's work. ${ }^{22}$ The French translation, Traite de l'hevre de la Mort, published in Antwerp in 1594, also mentions Van den Dale by name. ${ }^{23}$ The Brussels rhetorician Iehan Baptista Houwaert adapted the work in De Vier Uterste, printed in Antwerp in 1583, without acknowledging the model. ${ }^{24}$ Van den Dale's book was also used in the class room. In 1577, the Synod of Ypres allowed it to be read by the youth of the diocese. ${ }^{25}$ It was still in use in the schools of Antwerp and Malines in the seventeenth century. ${ }^{26}$

\section{The Theatricality of a Printed Poem}

The only surviving copy of the Van der Noot edition, in the Bayerische Staatsbibliothek in Munich, is bound with two fragments of another poem. Van den Dale's booklet is dated around 1516 because this poem by his fellow rhetorician Jan Smeken describes the festivities in honor of the meeting of the

19 We do not know the winning poem, it seems to be lost. Cited from Spelen van Sinne, 'Totten goetwillighen leser' ('To the benevolent reader').

20 The Van der Noot edition, according to Herman Pleij, was the first literary text printed in Dutch that had the name of a living author on its title page. Pleij, Het gevleugelde woord, p. 382 .

21 Degroote, Jan van den Dale, pp. 54-58. De Groote mentions a Leuven edition of 1543, Antwerp 1550, and Ghent 1576; an edition of 1601 and an Amsterdam edition of 1714. The Short Title Catalogue Netherlands mentions a 1636 Gouda edition, Delft 1650, 1652; Amsterdam 1685, 1710, and a Dordrecht edition, late seventeenth or early eighteenth century. The Amsterdam 1714 edition mentioned by De Groote might be the 1710 edition.

22 Arens, 'De Wre vander doot: De Hora Fatall'.

23 De Groote, Jan van den Dale, p. 49.

24 Ibidem, pp. 23-25.

$25 \quad$ Ibidem, p. 49.

26 Ibidem. 
Order of the Golden Fleece celebrated in Brussels on October $26,1516 .{ }^{27}$ Van den Dale's poem might even be subtly referring to this event. ${ }^{28}$ The Van der Noot edition has four unique woodcuts of scenes described in the poem, of which one is on the title page, and two others are used twice. The fifth woodcut follows the last stanza and is the printer's mark, showing a Knight of the Sea rising from the waves holding the Van der Noot coat-of-arms. The printer's mark lacks the usual Van der Noot motto 'Ic sals ghedincken' ('I will remember') in the banner. ${ }^{29}$

The woodcuts represent four crucial scenes from the poem. The title page shows the narrator-rhetorician indulging the sensuous pleasures of his youth in a lustful garden. The image is repeated between stanza 4 and 5 . The woodcut in-between shows a rhetorician slumbering in his study; an image repeated between stanzas 93 and 94 when the poet decides to make his last will. A woodcut representing Wraecghier (or death), the rhetorician and five fleeing women (his senses), between stanza13 and 14 closely follows the description in stanza 23. A final woodcut, also used twice, represents the main figures of the allegory: the beast and his bow threatening a rhetorician supported by Our Lady with the Infant Jesus who holds a little clock and a hammer. The five women are witnessing from a small distance. ${ }^{30}$ These woodcuts could easily be representations of tableaux vivants. The text resembles the script for a performance, and text and woodcuts must have helped readers to simulate a performance in their minds, or even to create a live entertainment in the company of friends. ${ }^{31}$

The paradoxical link created in the poem between texts and events is made explicit in that the first-person-narrator underlines the need to carefully read and study the text, while the problem of making such a text (as the reflection of

27 De uure vander doot bij Jan Van den Dale, [Brussels, Thomas van der Noot, ca. 1516]. Bayerische Staatsbibliothek München, Inc. s.a. 1906. The text is followed by the two fragments from Smeken's 'Beschrijving der feiten van het gulden Vlies te Brussel in October 1516', which lacks title page and printer's mark. A complete edition of the 37-stanzas poem is in the Ghent University Library. According to De Groote the Ghent edition differs slightly from the one in Munich. Contrary to De Groote's claim, the poem is not inserted into the Uure but separately bound with it. I quote from De Groote's edition which is available online (DBNL).

28 Stanza 10 is the description of a garden as beautiful as the garden 'daer iason de ghulden appelen haelde' (where Jason took the golden apples), a direct reference to the myth of the Golden Fleece.

29 De Groote, Jan van den Dale, pp. 54-55.

$30 \quad$ Ibidem.

31 For the link between text, image, event, performance and reading in company, Pleij, Het gevleugelde woord, passim. Also De Groote, Jan van den Dale, p. 22. 
an experience) is intimately interwoven into the narrative. ${ }^{32}$ At the same time, the text constantly (theatrically) invokes a speaker addressing a live audience who narrates the story of his dream which is centered on a (theatrical) allegorical dispute involving the same narrator-rhetorician, 'I', confronting Wraecghier (or death); Our Lady and the Infant Jesus; and Five Women (the senses).

The poem's language itself is highly theatrical which combined with the woodcuts also suggests that it was meant to be performed at an actual event, probably at New Year's Eve. Various references in the text invoke a performance-situation in which the poem's narrator and main character identifies as a scholarly rhetorician addressing a large and socially diverse audience and ending his performance by handing out the printed version as a New Year's gift. The same book becomes part of the 'act' when the narrator-rhetorician explains why he composed the poem and begs his audience to study it for at least one hour. He then adds that 'it is the final hour, as you must know, before your New Year. I call this booklet the Hour of Death, which might not be a very witty name as it should have been. It is dedicated to your wisdom and knowledge. ${ }^{33}$

The printed booklet thus could be the representation and commemoration of a performance that had shown a rhetorician narrating (on stage) the story (of a dream) within a story (of a rhetorician experiencing, pondering over, and struggling with his memory). The performance might have been the work of the author (Van den Dale), or of another actor impersonating the rhetorician. To complete the play of text and event, the author took the mirroring of the present world and the present text in the poem to its final consequence by including the gift of the printed booklet, which contained the poem, in the narrated event (of a rhetorician addressing his live audience). The playful selfreferentiality is a beloved theatrical technique of the rhetoricians, and invites the reader-audience to engage in the fiction.

Having made the role of the narrator in the creation and multiplication of the text so explicit, the text also invites to engage with his struggle to create a meaningful text out of a traumatic experience (the dream). The role of the rhetorician-narrator undermines or at least destabilizes the writing of an ars moriendi in such an explicit way that the poem almost transforms into an art of rhetoric. It is not entirely clear, and it might even have been intended to stay a riddle, or at least remain hard to decipher, to what extent the ars moriendi has

\footnotetext{
32 Particularly in stanza 1 and 2, and 99-114.

33 Also De Groote, Jan van den Dale, stanza 113, lines 1515-25.
} 
indeed become an art of rhetoric. ${ }^{34}$ Probably the two were so intricately interwoven to provide a vivid illustration to a fundamental argument about the use and abuse of the art of rhetoric, about its truth-seeking ends in the service of the common good: that is, provide moral guidance and prophetical warnings, and help citizens to be always prepared for their hour of death. ${ }^{35}$

At the end the rhetorician-narrator claims that he could only verbalize the experience with great difficulty and effort and without fully reaching the intended effect. The topos is not just the usual rhetorical modesty formula meant to move the audience in favor of the rhetorician; it was part of a treatment of the rhetorical gesture by explicit references to the problem of verbalizing experiences that was invoked throughout the poem. It would lead too far to analyze in detail the various clues that point to a (theatrical) reading of the text as an art of rhetoric wrestled from an ars moriendi. The focus here will be on two linguistic aspects of the poem's rhetorical method: the use of translation and the self-consciousness of the rhetorical language in the use of various sociolinguistic registers or jargons. ${ }^{36}$

\section{Two Types of Translation}

Van den Dale's Uure vande doot was part of the wider exchange of texts, ideas, and practices from, particularly, French culture into Dutch that has been discussed before. The first movement focused on the adaptation of the French rhetorical paradigm into Dutch around 1450. It was characterized less by the translation of specific texts than by the adaptation of a set of opinions on the use of rhetoric and of a selection of technical terms and practices. ${ }^{37}$ The

34 The Uure was linked to a series of texts beginning from the fifteenth century onwards, particularly in the same regions where the seconde rhétorique and Dutch rhetoric flourished. The theologian and Parisian professor Jean Gerson, who held benefices in the region (for example in Bruges), was one of the founding fathers of the genre. See for example, Bayard, L'art du bien mourir au $x V^{e}$ siècle. While in the 'traditional' formula a man on his death bed is tempted and finally dies in peace through the intervention of saints and the means of grace, these elements are abandoned in the Uure, as in its model by Pierre Michault. See also Pleij, Het gevleugelde woord, pp. 383, 679 who recognizes the reflexions on the art of rhetoric, but has a traditional reading of the poem as an ars moriendi, be it an innovative and untraditional one.

36 These issues were already highlighted by De Groote, Jan van den Dale, pp. 16-27.

37 Still, around 1464 the Brussels rhetorician Colijn Callieu translated an earlier text from the ars moriendi tradition, Pas de la mort by Amé de Montgesoies as Dal sonder wederkeren. Pleij, Het gevleugelde woord, pp. 672-73. Le Chevalier Déliberé by the Brussels rhétoriqueur Olivier de la Marche, and the famous morality play Elckerlyck (Everyman) have been linked to this cluster of texts as well. See also ibidem, pp. 670-80. 
second movement focused on individual texts instead, and was linked to the establishment of the printing press in the Burgundian Low Countries. Various French texts were printed in original and translated versions in the Dutchspeaking lands, including texts by the priest Pierre Michault (d. 1465), secretary to Charles de Charolais. He was known with Georges Chastellain and Jean Molinet as one of the fifteenth-century Burgundian rhétoriqueurs. His allegorical poem Danse aux Aveugles was printed around 1480 by Collard Mansion in Bruges. Geraert Leeu of Gouda printed Van den drie blinde danssen, a translation in prose and rhetorician poetry in $1482 .{ }^{38}$ In 1486, Johannes Andree of Haarlem printed the Doctrinael des tijds, a translation of Michault's Doctrinal du temps présent, another allegorical poem. ${ }^{39}$ De Groote has argued that Van den Dale's Uure vande doot was inspired by Michault's Danse aux Aveugles, either of the original French or its Dutch adaptation. ${ }^{40}$

In Michault's allegorical text, alternating between prose and poetry, description and dialogue, Entendement ('Understanding') shows l'Acteur ('the Author') that all of mankind will have three dances in their lifetime, showing him these stages by visiting three ball rooms. In the first, people dance before a blindfolded Cupid sitting on a throne. In the second room, people dance before the blindfolded Fortune, a crowned Queen. In the final room, the people dance before 'une chose moult hydouse' of which l'Aucteur thinks 'que ce fust ung monstre. ${ }^{41}$ It turns out to be Mors ('Death'), indiscriminately striking people by his lightning. At the end of his dream the author faints and awakens frightened, reaching for his pen. ${ }^{42}$

38 The intertextuality is discussed in Pleij, Het gevleugelde woord, pp. 673-77. The poem was translated by a certain 'clercxkijn martijn' (Clerk Martin). According to Pleij, the Dutch translation strengthens the central antithesis of reason and wisdom versus nature and the senses that is already evident in the original. The urge to use reason in the speculation and consideration of experiences is also present in Jan Pertcheval's prologue to the edition of his translation of Le Chevalier Délibéré, printed as Camp van der doot in 1503 in Schiedam.

Pleij, Het gevleugelde woord, pp. 504-05. This text alludes to similar themes of the use and abuse of reason and language that run through the cluster of texts under discussion.

40 De Groote, Jan van den Dale, pp. 17-23. I accept his arguments. A manuscript of La Danse aux Aveugles kept in the library of the Dukes of Burgundy was published in La Danse aux Aveugles et autres poësies du xv siecle extraites de la bibliotheque des Ducs de Bourgogne, se vend chez A.J. Panckoucke, a Lille, Libraire. Lille, 1748. I have used this edition of Michault's text which is available through Google Books.

41 La Danse aux Aveugles; De Groote, Jan van den Dale, pp. 17-23.

42 Ibidem. 
Whereas throughout Michault's text Entendement is guiding l'Aucteur by explaining and interpreting what is going on, in Van den Dale's text the rhetorician has to struggle alone. The fact that Entendement is cut and l'Aucteur, a witness in the original, has become a rhetorician who is part of the action, certainly alters the meaning of the text. It is now centered on the struggle of the rhetorician with the frightening beast and on his difficulty in verbalizing the events. The Gouda version was a free adaptation that kept much of the original structure intact. Van den Dale however profoundly reshaped and redirected the text: also cutting the allegorical figures of Cupido, Fortuna, Venus, Accident, Maladie, Creacion, and others; and reducing the three structuring dances to only one at the fringe of the narrative. ${ }^{43}$

Van den Dale's poem was at least as theatrical as Michault's original even though the latter used an explicitly scripted exchange between Entendement and l'Aucteur, whereas the confrontations in Van den Dale's poem are narrated in the rhetorician's monologue. The focus of the narrative is changed from mankind and its three dances to the individual rhetorician, his experiences, his struggle to memorize them in writing, and his pedagogical appeal to his audiences. Whereas Michault's text seems to discuss whether Man is governed by Reason or by all sorts of distractions, an interpretation that is also strongly suggested by the Gouda translation, Van den Dale turned his text into a discourse on the (in)adequacy of language. ${ }^{44}$

With the prose of the original removed, the allegory is entirely rendered in 1546 lines of verse and 110 rhyming stanzas of 14 lines each. The lines are in the free verse of the rhetoricians without a fixed number of syllables or regular meter. The rhyme is organized in two schemes: aab/aab/bc/bbc/cdd, and for the final, longer, stanza from bbc onwards in dcc/dde/fef. Various stanzas use double-rhyme, internal rhyme, alliteration, and enjambment. Unlike in the refrein, but also unlike Michault's text, each stanza concludes with a unique sententio and the final stanza has an acrostic on the name Jan van den Dale. ${ }^{45}$

Thus, the text has become a poem in the form and language of the Dutch rhetorical tradition, yet different from the typical refrein, which was one of the main genres used in meetings of rhetoricians and particularly in their contests and festivals. The unusual form, theatricality, and length of the poem suggest that it was meant for a New Year's celebration, attended not only by

43 Ibidem.

44 Ibidem.

45 De Groote, Jan van den Dale, pp. 50-51. A similar undertaking by Colijn Callieu who used stanzas of 9 lines concluded with a proverb in his translation of Pas de la Mort in Pleij, Het gevleugelde woord, p. 673 . 
rhetoricians, but by a large, and socially diverse audience made 'present' in the text. Such theatrical elements, referring to an 'outside world' in which the text is 'performed', are absent in Michault's text. ${ }^{46}$

Van den Dale has verbalized the visual and the performative in detail, which is a second type of translation used by the rhetoricians: the translation of experiences, acts, events, and thoughts into verbal language. It must suffice here to explore the role of Wraecghier as just one example of the poem's intermediality. Wraecghier is the terrifying beast that comes to claim the life of the joyous rhetorician who is absorbed in the pleasures of his senses and is unprepared to meet his Maker. The procedure, by which he acquired a proper name which is also his class-name, is through a pun on wraakgierig ('Revengeful') and aasgier ('Vulture'). ${ }^{47}$

The abstract concept of 'death' is animated by naming an amalgamated monster of (an-) organic, animal, and mechanical parts. The beast that in a sudden darkness flew out of a foggy cloud had a hellish and infectious stench that made the rhetorician stumble. Although Wraecghier is known to the rhetorician-narrator by its proper name immediately, he does not understand its nature. It is described as an 'abuselijck wondere' ('an erroneous wonder'); a fiery, horrible, thundering lightning and a strong tempest, a hellish devouring entity flying fierce and fast to bring 'me' down. The narrator underlines how difficult it was to say if this strange and frightening appearance, angrily aiming its tall black bow, were a spirit or a monster, an animal, or a beast. ${ }^{48}$

The rhetorician, still shivering with terror, while thinking, spelling, and writing of this attack only manages to describe the beast in detail in stanza 23. The cruel and bloodthirsty animal had the gruesome head of a lion, a chest made of soil, a scorpion's tail, the claw's of a dragon; it was infectious, venomous, crusty, long and thin, with a skin of barks, a Basilisk's eyes, and huge wings which made it move swiftly and in the blink of an eye. The beast stood on two iron legs, and spoke with a thundering voice. In his description of Wraecghier Van den Dale's language is most sensuously mimetic; by invoking many experiences caused by a traumatic clash between senses and the world. ${ }^{49}$ Of course,

\footnotetext{
46 De Groote, Jan van den Dale, p. 22 also refers to the dramatic, scenic potential of Van den Dale's poem as well as Michault's text: 'both poems would easily be rendered into a popular (volksche) performance'.

47 De Groote, Jan van den Dale, p. 82, stanza 15.

48 Ibidem.

49 De Groote, Jan van den Dale, pp. 86-87, stanza 23.
} 
the woodcuts in the booklet are a reminder that the rhetoricians also translated verbal descriptions into images.

\section{Jargons, Situations, Audiences}

The Uure vande Doot invokes various speech-contexts and audiences by using specific jargons which will finally be explored here as an important aspect of the rhetorician's method. ${ }^{50}$ It is written in rhetorical Dutch with hints of an eastern Brabantine dialect. Yet, more importantly than the regional coloring of the language is the alternation between a lyrical and mimetic language (a pure Dutch that includes the use of grotesque imagery, particularly in the description of the beast) and the scholastic jargons of the liberal arts, and of law and theology (using some Latin, and French in the dispute with the beast, the oratory directed towards the various estates, and the rhetorician's testament).

In Dutch rhetorical language two methods in particular were used to create a more abstract conceptual language: the first is the use of 'foreign' words, mainly from French, and to a lesser extent from Latin. The second method, also used frequently throughout the poem, turns adjectives into substantives. The other way round was to describe mental processes in materialistic and organic imagery, such as in Van den Dale's neologism oreeste: a mimetic term created to describe the sort of anger shown by Wraecghier. The word probably was a contamination of two Gallicisms: orage ('anger') and tempeeste ('storm' or 'tempest'). ${ }^{51}$

While the use of French words in the mimetic and lyrical stanzas remains relatively scarce (for a rhetorical text), in several stanzas suddenly the vocabulary shifts to an overflow of Gallicisms throughout the stanza but almost always in rhyme-position at the end of each line. The shift is always related to a change in the narrative structure from the position of a lyrical narrator (the 'I' remembering and trying to extract meaning from his experiences) to an authoritative 'I' (aiming to teach the lessons learned to a 'present' audience), or an 'I' that pleas and argues with Death, God, and with the estates of the world.

Of course, the 'present' audience is addressed throughout the poem by the narrator telling the tale of his dream-encounter with Death and the lessons he derived from it, which, in the structure of the poem is made explicit in the sententio, the proverb or other abstract truth or judgment that sums up a lesson related to the story or argument of that particular stanza but also to the

50 De Groote, Jan van den Dale, pp. 13-14 and 16. De Groote also points to the use of jargons and the nuanced choice of vocabulary relative to the audience.

51 De Groote, Jan van den Dale, p. 83, stanza 15. 
text's overall argument. Several times however, the narrator directly turns to the 'present' audience by way of apostrophe. The first time, interrupting his lyrical description of the wonderful pleasures of the first handsome lady, the rhetorician addresses 'you, merciful young man, why are you brooding, be joyful, suppress all sadness; are you suffering of fantasies, focus on cheerful thoughts. ${ }^{2}$ In the midst of his description of the joy caused by the five beautiful ladies (his senses), in stanza 12 the narrator-rhetorician suddenly turns to what might be interpreted as the poem's intended audiences, young men keen on the pleasures of life and young rhetoricians in particular:

Ghi ionghers van venus bloeye

Oft scuylende onder mercurius roeye

Peyst / denct / gheeft vonnesse / op dit bediet.

Oft $v$ onversien / niet op v hoeye.

Dit ghebuerde hoe v sou sijn te moeye.

You youngsters flowering from Venus

Or taking shelter under Mercury's scepter

ponder/think/judge/ what happened here

that if suddenly when you are not on guard

this happened to you, how would you feel? ${ }^{53}$

In stanza 105 the rhetorician-narrator concludes his 'argument' with reference to the scholastic argumentative method (summa, and ergo): 'somma, when I study the grounds, my experience teaches me' the meaning of this vision. He addresses the summary directly to the present audience, first to his fellow rhetoricians: 'so brothers, be on guard, our hour will come.54 Then to 'you, wise lights, you learned men' (stanza 106); 'o prelates, all religious people chosen by God' (107); 'all princes, you knights, noble estate' (108); 'you avaricious people, secular or religious, princes, prelates, merchants, rentiers' (109); 'young and old, adult and child, layman or cleric studying in my simple work to purify the spirit somewhat' (110). From the 'ergo' of stanza 111 onwards, the rhetorician concludes his lesson, and then, in the final stanza (114), turns to

$5^{2}$ 'So si v ionghelinck goedertieren, Wat peysdi sijt blije / wilt druck verdieren, Fanteseerdi weest vrolijck van ghedochte' (stanza 6).

53 Stanza 13 continues the lyrical description of pleasures, while in stanza 14 Wraecghier 'enters the stage'.

54 'Somma als ick doersoecke den gront, so maect mi expierencie cont'; 'dus broeders waect, ons ure sal comen wi worden verheert'. De Groote, Jan van den Dale, p. 126, stanza 105. 
God, dedicating his life and the present work to him, pleading on God's mercy, partly in the humble voice of a fearful subject, partly in the elevated rhetorical language of the privileged citizen invoking the plea of his dream, including the Gallicisms that belong to the language of the lawyer.

The rhetorician-narrator also employs apostrophes in his dream (stanza 3-98) that do not address a present audience, but an imagined audience that almost but not entirely equals the present audience. These apostrophes begin when, in a confrontation with Wraecghier, the rhetorician refuses to submit himself to Death, and begins a lengthy plea (from stanza 17) first begging for mercy in a language that slowly turns 'rhetorical', that is, elevated, in a juridical dispute with the beast, using technical terms such as gracie, spacie, termijn, avijs, respijt. When the beast remains unmoved; the rhetorician appeals to a higher authority, fully employing a juridical language that in the Dutch-speaking Low Countries was strongly interspersed with Gallicisms. The technical terms borrowed from the French are mainly employed in rhyme-position: appellere, justicie, spacie, officie, condicie, malicie, inhybitie, protesterick ('I protest'), avijs. The beast though was well-matched and responded by using technical terms such as argueren, appelleren, justicier, executie, lamenteren, delayeren, gepasceert, parlement, execucie, princhier, justicie, solucie, terminen, respijt. In stanza 21, the rhetorician refers his adversary to the correct juridical proceedings, continuing in his language full of Gallicisms. ${ }^{55}$ Wraecghier answers in stanza 22 that 'even if you were eloquent as Tullius, had Samson's power, Solomon's science', this would not matter. ${ }^{56}$

The rhetorician, once he fully realizes what the beast looks like, responds in a highly lyrical, musical, melodious language full of double-rhymes that mimics the process of a fainting rhetorician gradually regaining his strength, finally forcefully demanding the beast to reveal its credentials. The beast responds to the challenge, but (in stanza 26) the rhetorician questions the coherence of his answer by submitting it to the rules of scholarly logic: 'as the doctors and philosophers teach: two mutually exclusive antitheses in one sentence cannot both be true. ${ }^{57} \mathrm{He}$ then challenges the beast further to use the formal rules of reason ('how, what, to whom, and through what and prove with reason what

55 Stanza 21, Gallicisms: fantasien, absencien, partien, enuien, suspect, vermalendien, fortse.

56 Stanza 22: 'al haddi tulius eloquencie, sampsoens macht, salomons sciencie'. Gallicisms: eloquencie, sciencie, mencie, execucie, sentencie, gracien, excusatie, ocsuyn (occasion).

57 Stanza 26: 'want so doctoren philosophen doen vermaen, twee contrarie en moghen niet tsamen staen'. See also the remark by De Groote, Jan van den Dale, 16. 
you are allowed or should do'). ${ }^{58}$ When finally the beast reveals to be Death himself, the rhetorician almost faints again, understanding his fate is sealed, just his tongue, still not defeated, begins to plead (again using the Gallicisms of juridical language) for delay from a year down to a day (stanza 33-37) to settle his accounts. ${ }^{59}$ While he succeeds in annoying the beast, the rhetorician is suddenly saved for another hour by a beautiful joyful lady, who, in juridical language, commands the beast to obey and grant the rhetorician some mercy. The lady, a higher authority, is later 'explained' by the narrator-rhetorician to be Mary.60

The rhetorician, thus granted one hour of grace, laments that he does not know what to do or where to start and finally addresses the hour ('o hour', stanza 42). He than decides to make his accounts 'with little memory for lack of paper', and calls upon his senses ('o sinnen') for help, using technical terms of the rhetorical paradigm as gestudeert, gefantaseert, speculacie, subtijlheit, gracie, spacie, sciencie, falacie, regnacie, sentencie, eloquencie (stanza 44). He than resumes his lament by addressing time ('och tijt', stanza 45-47), and continues with an old genre from the French rhetorical tradition, an 'adieu' to the world (stanza 49-51) that also uses a highly rhetorical language including the typical Gallicisms. ${ }^{61}$ The 'adieu' to the world ends on a different note when the rhetorician turns from a lament to an accusation and finally to an abuse of the treacherous world of deceitful appearances. ${ }^{62}$

An intermezzo of self-pity is followed by an accusation of the morning ('o morning'). Another intermezzo of self-pity ends with an appeal in seven stanzas of highly elevated language to all estates to take lesson from the spectacle of the beast. Particularly the stanzas addressed to the prelates (58), the nobility (59), the merchants and rentiers (6o) are rich in double- and internal rhyme (58-6o) that create a lofty language. The appeal to the avaricious people lacks these qualities as does the invitation to all the estates, nobles, women, and poor to take part in the dance of death (62). The appeal to the poor laborers, calling for patience, only uses double-rhyme, and the call to the

$5^{8}$ Stanza 28: 'bruyct redene hoe wat aen wien waer bi en met renen laet blijcken wat ghi moet of muecht'.

59 Stanza 31, Gallicisms: speculacie, contrarie, allegacie, contradixie, lacen, gracie.

6o Stanza 38, Gallicisms: gheoerdieneert, respijt, gheconsenteert, obedieert, opponeren.

61 Stanza 49, Gallicisms: adieu, glorie, concistorie, lacen, memorie, pompuese, ciborie, miserien, horrible, ghefenijnt, aylacen, memorie.

62 Stanza 52, Gallicisms: princersse, variable, gheinfecteert, samblans, fortuynen. 
devout hearts or those living under a religious rule again employs some technical terms derived from French referring to their religious duties. ${ }^{63}$

The appeals to the estates are followed by a long lament to the Lord that is reminiscent of the penitential Psalms. The tone becomes worldlier in stanza 80 when the rhetorician begins to plea for mercy as if addressing a prince. Stanza 83 in particular is highly juridical, lofty, and rhetorical with many Gallicisms in rhyme-position. It moves from the lofty language of the citizen pleading for his rights into the humbler tone of a subject pleading for a sovereign's mercy (83), until the rhetorician finally acknowledges his misdemeanors, pleads on his human weakness and the human nature of the Lord and his suffering (85-86). In stanza 87 the rhetorician changes tone, now again appealing to the Lord as a temporal prince, to his law and his sovereign prerogative to correct the guilty or be merciful, referring to authorities such as Jeremiah and St Augustine, Matthew and Mark, as if he were in a court of law (88-93). In stanza 94, the rhetorician realizes that all the time the beast has been watching and the sound of the hammer has been indicating the lapse of time. Since the five women have moved closer the rhetorician decides to make them witness to his last will. While donating his goods to nobles and commoners, to princes and prelates, in order to be remembered in their prayers, the hour sounds and the beast aims its bow. The terrifying fear of death awakens the rhetorician, shivering, drenched in sweat and bleeding from his nose (98).

Van den Dale's ars moriendi diverges fundamentally from the rules of the genre; the narrator-rhetorician who was destined to die, at least in his dream, never dies. Also lacking is the generic role of a priest, the saints, fear of purgatory, and the means of grace of orthodox Catholicism. These generic features were already ignored in Michault's combination of an ars moriendi with the theatrical concept of the dance macabre into a text structured as a dialogue between Understanding and the Author. Michault's text seems to have been focusing less on Death than on Mankind's lack of reason, whereas Van den Dale's text, structured as a rhetorician's monologue, is converting the ars moriendi into a reflection on the art of rhetoric and the trouble of speech in the face of moments of truth (represented here by the final and most significant moment of truth, the hour of death).

In a way, the transformation of the ars moriendi into an art of rhetoric already is a lesson to young rhetoricians, who are singled out as a significant first audience. The poem could be read as a statement about the nature of their art showing that the aim is not to imitate existing examples or copy existing

Stanza 64, Gallicisms: mencie, penitencie, abstinencie, patiencie. 
templates, but to create new texts that use, adapt, and emulate tradition. Whether or not this was intended by Van den Dale and understood by his audience, the structure of the poem certainly shows that it was explicitly intended to deal with the problem of genre as a means to address specific audiences and serve specific persuasive purposes. The text employs two structural positions: the citizen (a free person with rights and privileges) versus the subject (a dependent person in a state of mercy) corresponds to the use of rhetorical versus lyrical and language, and to the use of a hybrid versus a pure language.

On a more specific level, the text shows various speech situations, from pleasant conversation, formal instructions, inquisitive enquiry, juridical disputation, pedagogical oratory, formal pleas and charges, lamentations, accusations, farewell speeches, narratives and tableaux vivants to specific genres such as the proverb, the testament, the prayer, and the penitential psalm. All of these genres are related to situations that vary between private and public forms of speech, lofty and low use of language, depending on the role and intention of the rhetorician and the audience he choose to address. The display of these situations and the related uses (and abuses) of language and speech forms are key to the interpretation of Van den Dale's poem as a highly personal art of rhetoric, or even, as his rhetorical testament containing the programmatic legacy of a rhetorician's teachings of the art. ${ }^{64}$

\section{Conclusion}

Dutch theatrical-rhetorical culture depended on multilingualism in three fundamental ways. Because of their interest in acquiring and disseminating learning and the culture of learning, leading rhetoricians, such as Van den Dale, were often multilingual people that worked to translate and adapt learning from mainly French, Latin, and Dutch sources. They shared their knowledge with fellow rhetoricians and their local communities mainly through rhetoricaltheatrical means which were the second fundamental impulse of the use of languages in a broad sense: the use of language relative to the speaker and the audience. A third, metaphorical, way in which rhetorical culture was 'multilingual' was through the use of non-verbal language or the mimicking of these languages in verbal language.

64 Pleij, Het gevleugelde woord, p. 383 points to the explicit references to the art of rhetoric in the poem, particularly the notions of inventio, materia, elocutio, actio. 
The hybrid language of the rhetoricians in a way was carved out in between Latin and French languages, existing Dutch languages and visual and performative languages. Their use of language reflected the communicative practices of the early modern period, before and well after the introduction of the printing press. Their rhetorical wit was highly adapted to a world in which written texts remained scarce, and the oral, visual, and performative means of face-toface communication and its mnemotechnics were predominant. It is likely that the written text in the vernacular became more dominant in the course of the seventeenth century, which might explain why the role of face-to-face interaction was reduced, the hybrid nature of Dutch literary culture was attacked and successful attempts were made to purify its language. 